\title{
Collaborative Environments in RD\&I Institutions of the Brazilian Agricultural Sector
}

\author{
Tércia Zavaglia Torres', Ivo Pierozzi Jr.2, Ricardo Martins Bernardes ${ }^{3}$, Isaque Vacari ${ }^{4}$
}

\begin{abstract}
Research, development and technological innovation (RD\&l) companies promote inter- and intra-organizational interactions based on the formation of research nets. This arrangement prioritizes the use of competencies of both people and institutions, stimulating the generation of new knowledge and competencies, and consequently technological innovation. The Brazilian Agricultural Research Corporation - Embrapa, responsible for knowledge generation and technological innovation in the Brazilian agricultural sector, has put a lot of effort into the establishment of a collaborative environment which allows the exchange of information, knowledge and experience among researchers and promote new knowledge, competencies and technological innovation. The present paper discusses conceptual bases and presents a model of collaborative environment established by the above-mentioned corporation in order to favor the learning and the production of innovative solutions in agricultural research nets.
\end{abstract}

Key words: collaborative environment for technological innovation; collaborative learning for technological innovation; integrated knowledge nets; knowledge net management.

\footnotetext{
I Embrapa Informática Agropecuária, Universidade Paulista - Unip, Faculdades de Paulínia - FACP. Avenida André Tosello, 209 - Barão Geraldo. Caixa Postal 604I. I3083-886 - Campinas, SP. Brasil. Tel: 0055 19 32II-5785. Email: tercia@cnptia.embrapa.br

2 Embrapa Informática Agropecuária. Avenida André Tosello, 209 - Barão Geraldo. Caixa Postal 604I. I3083-886 - Campinas, SP. Brasil. Tel: 005519 32I I-5867. Email: ivo@cnptia.embrapa.br

${ }^{3}$ Embrapa Informática Agropecuária. Avenida André Tosello, 209 - Barão Geraldo. Caixa Postal 604I. I3083-886 - Campinas, SP. Brasil. Tel: 005519 321 I-5802. Email: ricardo@cnptia.embrapa.br

${ }^{4}$ Embrapa Informática Agropecuária. Avenida André Tosello, 209 - Barão Geraldo. Caixa Postal 604I. I3083-886 - Campinas, SP. Brasil. Tel: 005519 321 I-5784. Email: isaque@cnptia.embrapa.br
} 


\section{Net Structures in the Knowledge Society}

The productive system is focused on the paradigm of the "Knowledge Society" (Geus, 1997), which leads companies to understand knowledge and information as strategic organizational elements. It is evident that companies need to widen their technological innovation capacity to assure higher flexibility, increased productivity and differentiated products/services. This impels them to promote constant changes and adaptations in their guidelines, action strategies, politics, and management practices.

Among the environmental factors that contribute to this reality, those related to the advances in Information and Communication Technologies (ICTs) mostly affect the constitution of knowledge valorization as a resource that generates richness (Nadler and Tushman, 2000). Based on such rationality, companies are in increasing need of managing the knowledge they produce at the same time they have to create organizational conditions/structures capable of allowing their survival in markets under constant changes (Soo et al., 2002).

For RD\&l institutions, this reality seems to be more evident since the complexity of research problems and the interdependence of several knowledge domains required for the promotion of integrating solutions, associated with the dynamicity of the environmental conditions, have made these institutions develop excellent communication channels and information systems/repositories capable of constituting a knowledge base, anchored in a process of continuous learning.

On one hand, the knowledge, as input and basic product of these institutions and, on the other hand, the organizational structure as a factor favoring its generation. The way RD\&l institutions structure/organize their management logic is therefore essential to face the challenge of satisfying external demands. According to Fischer (200I), companies engaged in the knowledge industry have better conditions of using the benefits of eventual growth cycles, especially if they invest in the interaction and interchange of efforts to create an institutional context wont to the enhancement of their capacity of generating new knowledge and competencies (Santos, 2007).
Establishing interactions with several internal and external actors becomes thus imperative for these institutions since it leads to the possibility of widening their innovation capacity. A strategic alternative for this is the formation of research nets. According to Bulgacov and Verdu (200I), institutional nets, especially research ones, attempt to seize the available opportunities in the development of an actuation field, assuring autonomy and independence for each participant due to complementary actions favoring the achievement of common goals.

The nets are focused in the competencies of people and institutions, which are essential to promote broader, systemic and creative solutions. The central idea of the institutional arrangement based on the net concept is that the latter allows internal and external actions to be simultaneously performed, creating a more favorable environment for the generation of new knowledge, competencies, and consequently technological innovation (Tushman and Nadler, 1986).

In RD\&l institutions, the relationships of partnership, cooperation and interdependence built with the establishment of nets are an innovation in the form of organizational management since they require new institutional arrangements to allow integrating solutions (Gramkow, 2000). There are two relationship levels in institutional nets. The first level assures an internal integration among work teams in order to maximize the efforts for the collaborative production between peers. The second level tries to develop mechanisms of external articulations directed to strategic evaluation. For both levels, the underlying premise is that of collaboration and cooperation.

The net structure induces collaboration, cooperation, collective work and shared management, becoming thus one of the most compatible forms of production, synthesis and distribution of ideas in research actions since it generates the base for the technological innovation process. However, the constitution of internal and/or external nets requires efforts by RD\&l institutions towards the establishment of internal management politics and practices that favor the creation of competitive advantages while fulfilling the external challenges. 
The conception of nets brings numerous advantages for the promotion of technological innovation in RD\&l institutions since, based on the multiple relationships established, the net can expand, integrating new participants due to the sharing of communication codes (Castells, 1999). An organization by nature is interlinked to the several internal and external connections established with its partners. Figure I exemplifies a highly connected interinstitutional net, with all three important partners ( $A$, $B$ and $C$ ) building, based on the inter-relationships they maintain, a higher possibility of producing results since, even when one of the participants leave, the previously established relationships are not weakened.

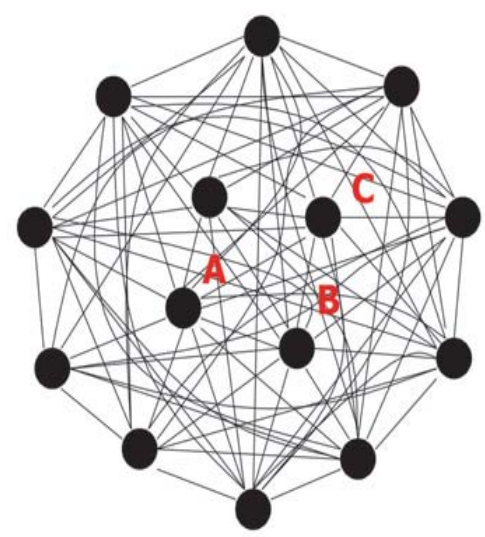

Figure I. Example of Productive Organizational Nets. Source: Brasil (2007)

This example indicates that the quality and the reciprocity in the relationships maintained by these institutions are basic and strategic factors for success and must therefore be objects of great attention since the effective management of these relationships can enhance the chances of reaching desirable results. Thus, organizational results are due to the effective management of the interconnectivity dynamics and the dialogs promoted by the company interacting with several actors, either internal and/or external. The capacity of making simultaneous connections allows the net expansion and favors the dissemination of information, knowledge, competencies and experiences. The diffusion of such intangible assets is done in the nets,

... in a decentralized manner, by interested participants themselves, interacting with one another. The diffusion occurs rapidly since the connections each person promotes make the Net and the information circulating in it - advance a little - ... Since all participants have this same behavior, the Net produces a considerable movement of propagation and spread. Processes that accelerate knowledge diffusion and experience exchange are essential to promote development (Brasil, 2007, p. 24).

From the organizational management point of view, the net perspective suggests that the relationships established by the companies with their internal (first level) and external collaborators (second level) are not immutable or static. Instead, they are under constant change and can be built, reproduced and altered based on the type of actions performed by the actors integrating it. This understanding leads to the idea that nets are arrangements that are more favorable to RD\&l institutions in the current context of the knowledge society, since they represent an interconnectivity among relationships and also give the idea that the organization has a fractal character, i.e. its relationships change and are molded interdependently according to the type and nature of the relationships established among the authors involved in it (Tôrres, 2005).

Managing the way established relationships, of both first and second level, occur is therefore essential since it maximizes the opportunities to reach the results (Baker, 1992; Jones, Hesterly and Borgatti, 1997). 


\section{The Emergence of Agricultural Research Nets}

The Brazilian Agricultural Research Corporation (Embrapa), a public company associated with the Brazilian Ministry of Agriculture, Livestock and Food Supply, has the mission to make available solutions of research, development and technological innovation for the Brazilian society. To fulfill its role, Embrapa has established a research model, Embrapa Management System, which is focused on the development of technological innovation process and on the intensification of sustainable development.

The Embrapa Management System prioritizes the efforts of integrated articulation and the formation of multiinstitutional research nets. In this articulation, the Embrapa Management System emphasizes the interdisciplinarity and the use of several resources, especially intangible ones, to produce innovative technological solutions, indicating that one of its basic premises is the social interaction among the people in research projects.

Three concepts support the Embrapa Management System: interdisciplinarity, integration and transversality. Interdisciplinarity can be understood as an act of exchange and reciprocity among disciplines or sciences - of knowledge areas (Japiassu, 1976). The execution of interdisciplinarity implies "penetrating into the deepest tissue that constitutes the reality to be investigated, articulating knowledge to social dynamics" (Frigotto, 1995). The concept of integration complements that of interdisciplinarity, especially because it incorporates the idea of unity among the forms of knowledge and their respective disciplines (Santos Filho, 1999).

According to the conception of transversality, the construction of knowledge is a collective process and the way we conceive and address research problems is not compatible to the complexity degree that is observed when we approach these issues trying to solve them. The current problems are complex because, besides covering several knowledge areas, they also address varied instances of the human life dimension, forming a cartography that is difficult to understand from a disciplinary point of view (Gallo, 2000). This means that researchers are required to introduce new rationality into their distinct domains and disciplinary specialties so that they can build bridges and pass through the several forms of knowledge with the aim of establishing multi-comprehensions that make them cover the infinity of relationships inscribed in the problem complexity itself (Gallo, 2000).

These concepts require a new paradigm in Embrapa which could make the researchers' reflection process prioritize an intrinsic relationship among the several areas of learning and knowledge. This justifies the proposal of a conceptual model to support the construction of a collaborative environment for RD\&I projects in the company nets. Such an environment must favor the transit among the several forms of learning and knowledge produced by their researchers over the development of the solution of research problems or management actions. This logic establishes a learning culture capable of facilitating the exchange of information, knowledge, experiences and competencies among people and teams, which amplifies the capacity of Embrapa to technologically innovate.

\section{ICTs and the Creation of Collaborative Environments}

Technology can be understood as artifacts that humans create to facilitate their life and expand their knowledge (Romanó, 2004). Among the several incorporated technologies, the ones that caused greater impact were related to the implementation of Information and Communication Technologies (ICTs), especially the Internet. The Web is a space that allows people to routinely (re)formulate their knowledge (Orlandi, 2004), facilitating the creation of new forms of relationships with knowledge, with ourselves and with the society (Dias, 2005); it is therefore an advantageous tool for scientific communication since it serves for collaboration and spread among partners integrating a research net.

The constant updates promoted by the technological advances in the field of computer science have shown that they are incorporating increasingly powerful and efficient mechanisms concerning time, space, costs and benefits. Of all these technological aspects, the one related to the possibility of people learning together, collaborating with one another, even when geographically distant, most calls our attention.

This virtual space (i.e. the group of non-predictable possibilities) based on human interferences with the 
formation of a dynamic and flexible collective memory is named cyberspace. The latter can be defined as a universe of possibilities in which individuals interact with it, explore it and update it at the same time (Lévy, 1999). Today, the technological advance in the cyberspace allows the engagement of a participative, dynamic and horizontal interaction with people and the construction of a collective product resultant of the relationships that occur in it. The current Web allows the co-authorship of products by offering dynamic pages, shared data bank, file exchange etc., which can be altered and enriched by all their visitors, making people become active interveners of the collective construction process instead of passive spectators (Fortes, 2006; Silva, 2006).

The cyberspace can also be considered a space for learning since exchanges and interactions that contribute to changing the behavior of people, relative to the world and the things surrounding them, occur in it. As a learning space, the Web allows broadening the interaction among people, which stimulates the construction of a collaborative culture (Scotta, 2009). One of the main principles of the cyberspace is to work the Web as a platform, i.e. to make viable online functions that in the past could only be conducted by programs installed in computers. This principle emphasizes the development of an 'architecture of participation' in which the informatic system incorporates interconnection and sharing resources that increases the chances of a person produce better results collectively (O'Reilly, 2005). This makes the cyberspace an integrated structure of functionalities and contents that can be considered a dynamic model of participation (O'Reilly, 2005).

In addition to favoring the construction of learning, the cyberspace provides a communicative bidirectionality, i.e. a type of 'many-to-many' communication. In this type of communication, any person can simultaneously be a consumer and a producer of information (Lévy, 1999). This means that the Web maximizes the creative potential of net research project teams from a high-quality interactive production, constituting a tool that increases the capacity of production and individual and collective knowledge (Rosado, 2008).

The more autonomous and interactive the virtual space built to promote collective interactions, the broader its potential to serve as a space for learning and building collective knowledge (Primo and Cassol, 1999). A virtual space is considered interactive when we can see the relationship of complexity, multiplicity, potentiality, interchangeability (combinatorial principle), unpredictability, non-linearity and bidirectionality, which allows users to freely participate and intervene (Aires and Ern, 2002).

Thus, ICTs play a relevant role in the formation and implementation of research nets since, in addition to promoting information and communication flow and allowing people to change their behavior (learn), they also facilitate their relationships with the organizations. This contributes to the management of the interconnections that occur in the relationships among the several social actors. Furthermore, ICTs favor the organization of the information and the generated knowledge and allow their dissemination, increasing the chances for companies to improve their results.

The greater the amount of information codified by the several authors that integrate the net, the higher the possibility of spreading it and the higher the chance for the net to reach its main goal, which is to maximize the use of organizational resources, especially intangible ones in order to create innovative, integrating, systemic and creative solutions to fulfill the needs of the environment (Child, 1987).

\section{4. e-I@r Embrapa: A Proposal of Conceptual Model}

When ICTs are used as a space for learning in a collaborative environment to manage the net of internal relationships that occur inside the research projects of Embrapa, it is essential to establish a conceptual model of the process of exchange and interaction of knowledge, experience and learning to maximize the opportunities that will allow researchers to interact, produce new knowledge and learn from one another. It is necessary to learn which characteristic the collaborative environment should have, as well as its main elements and how they integrate to facilitate learning and its management, also understanding the metaphors that guide the way the environment should be used (Schlemmer, Saccol and Garrido, 2007).

To satisfy all Embrapa's needs, this conceptual model must insert pedagogical criteria to consolidate the exchanges 
and interactions occurring in that environment and allow an accurate and interdisciplinary view about the way the knowledge construction and the learning process occur in the research projects and management actions of Embrapa.

To serve as formative context, ICTs must be understood as an infrastructure, i.e. groups of pre-existing institutional arrangements that allow the actors of the process to use their cognitive structures to produce integrated and collective actions. Activities that are collectively performed provide huge advantages, which are not available in individualized environments of learning (Vygotsky, 1998).

The subjects' constitution, similarly to their learning and thinking processes (intrapsychological processes), is mediated by their relationship with other people (interpsychological processes). This indicates that people are referential sources of learning that support our behaviors and reasoning, as well as the meanings we give to things (Damiani, 2008). The one who learns gradually 'borrows' mental models from their interlocutors who are more qualified, becoming able to overcome their limits (Alvarez and Del Rio, 1996). Thus, the other is an important and indispensible piece in the whole dialogical process which permeates the social interactions. Without the other, a man does not dive into the signal world, does not penetrate into the language current, does not develop, does not learn, does not evolve to superior psychic functions, does not form his conscience, and thus is not constituted as a subject (Damiani, 2008).

The act of thinking is nestled in socially organized and historically formed activities, presenting thus an interactive, dialogical and argumentative character. We can say that people develop and learn more when they are in a collective process of learning, when they share common meanings and representations, when they communicate and discuss their points of view, when they examine and improve their ideas or even when they establish a multidirectional dialog in which the proposed solutions are reviewed, widened, modified or opposed (Engeströn, 1994; Jeong and Chi, 1997).

There are two theoretical currents that can cover the conceptions for the proposal of a conceptual model of collaborative learning: empiricist and interactionist/constructivist (Schlemmer, Saccol and Garrido, 2007). The distinction between them is done based on the potentialities they offer concerning interactivity. In the interactionist/constructivist current, the communicational interactivity prevails and there is symmetry of language and fluency with mutual collaboration in the dialogical process. In the empiricist model, the interactivity condition is restricted to the mere possibility of actors contacting one another (Schlemmer, Saccol and Garrido, 2007).

The collaborative environment to be proposed for Embrapa's agricultural research nets has been entitled 'eI@r Embrapa'. To fulfill the previously discussed purposes, the interactionist/constructivist current must be adopted as the pedagogical-theoretical thread since it simultaneously promotes collaborative and cooperative learning. In addition, this thread stimulates people to participate in the learning process, considered active and effective, in which the built knowledge is a result of a dialogical and consensual process among the members integrating the environment (Romanó, 2004).

These characteristics will make 'e-l@r Embrapa' an environment that favors exchanges and interactions among researchers and their peers and teams in a procedural form adjusted to the social context to which they are circumscribed. This promotes mutual comprehension; stimulates the creation of a common language of shared meanings; facilitates the creation of capacitating context which is necessary to the propulsion of new knowledge; and develops solid social structures capable of consolidating an organizational learning culture focused on technological innovation. Authors like Nonaka and Konno (1998), Choo (1998), and Alvarenga Neto and Barbosa (2007) assume that the institutionalization of a space for exchange and interaction is essential for the creation of knowledge since it widens the exchange of ideas, suggestions and experiences, besides reinforcing individual and collective learning. An environment with such characteristics, in addition to allowing

... interactions among individuals, is constituted of information necessary to create knowledge nets ... The companies inserted in the innovation process are those that do not expect this to occur at random. These organizations take initiative to establish communication channels, not only among their internal collaborators, but also between them and the remaining external organizations (Santos, Botelho and Silva, 2006). 
The conceptual model elaborated for 'e-l@r Embrapa' is a matrix model composed of two analysis dimensions that complement each other (Figure 2). The first is cooperative, consolidating the technological infrastructure designed to facilitate the development/accomplishment of social interactions among people. This infrastructure is segmented into two perspectives of Web technologies adopted because they promote pedagogical aspects that favor the collaborative learning; they are the technical and the communicational-social perspectives (Schlemmer and Fagundes, 200I; Schlemmer, 2002). The technical perspective emphasizes the incorporation of technological tools directed to aspects of individual and collective work authorship, synchronic and asynchronic interaction, technological support and various services. The communicational-social perspective prioritizes the incorporation of tools enhancing the interactionist, communicational and social dynamics that will occur among people. The cooperative dimension in the conceptual model establishes the form in which Embrapa organizes its virtual space to make researchers closer to the institutionalized knowledge, i.e. knowledge directed to aspects concerning the areas of specific formation of people, which are thus considered formalized or explicit knowledge areas. This dimension provides the learning of essential processes that consolidate social interactions and are crucial since collaboration only occurs when people assimilate a common language of significance (Rockwood, 1995).

The second dimension of the conceptual model is collaborative. This dimension allows participants to collectively determine, based on social interactions, the tacit courses that should be followed to solve the problems they face over the execution of the research project or the management action they perform by using the institutionalized knowledge learnt from the cooperative dimension. The product of collaboration is the social learning of the 'work together' and that of exploring ways to help one another solve problems, contributing with analysis and playing a more active role both in their learning process and in that of their peers (Romanó, 2004). This dimension of the conceptual model of 'e-l@r Embrapa' inscribes the way participants build, based on the cooperative dimension, the non-institutionalized knowledge, the one named tacit because it is built from ideas, reflections and questionings resultant of the idiosyncrasies provided by the social interactions and/or by the personal experiences elaborated by researchers, individually and/or collectively, over the execution of research projects or management actions.

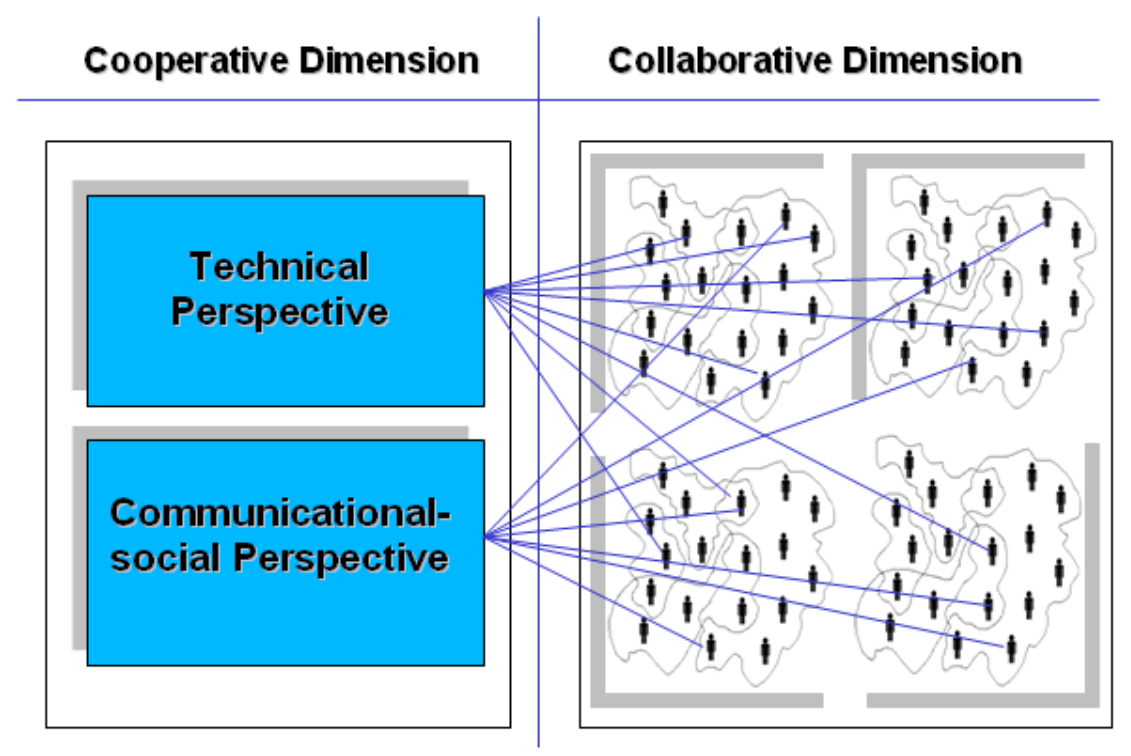

Figure 2. Conceptual model of 'e-l@r Embrapa'. Source: Adapted from Schlemmer (2002). 
In the collaborative dimension, communication among researchers and exchanges of experiences, ideas, opinions and criticism are the focus of attention. In this dimension of the model, the way social interactions occur, as well as relationship nets and interventions done by researchers in the research projects, can be noticed. This space will allow the stimulation and the enhancement of the exchange of institutionalized and non-institutionalized (tacit) knowledge. It will also be feasible to simultaneously capture the way learning occurs and the knowledge and competencies learnt by researchers over the execution of research projects.

In addition to this conceptual model, three organizational aspects must be highlighted because they need parallel care since the environment consolidation and institutionalization depend on them. They are communication, RD\&l project management and organizational culture processes. As these aspects are interdependent concerning the proposed conceptual model, this trilogy must be articulated since, to collaborate, researchers need to communicate, coordinate and create, generate, exercise, consolidate and institutionalize a group of rules, values and beliefs that support learning and knowledge generation.

This trilogy presupposes interdependence among these three concepts (Figure 3). Communication involves the exchange of messages and the negotiation of compromises. In the coordination/management of RD\&l projects, the researchers, the activities and the resources are directed to minimize conflicts and prevent loss of communication and collaboration efforts. The organizational culture represents the production of a group of rules, values, beliefs and collective meanings built by people in the space of shared social interaction which consequently generates a cycle that again demands an interactive, live and horizontal communication. These three concepts cannot be treated separately; instead, they need continuous actions that should be performed throughout the 'e-l@r Embrapa' building process.

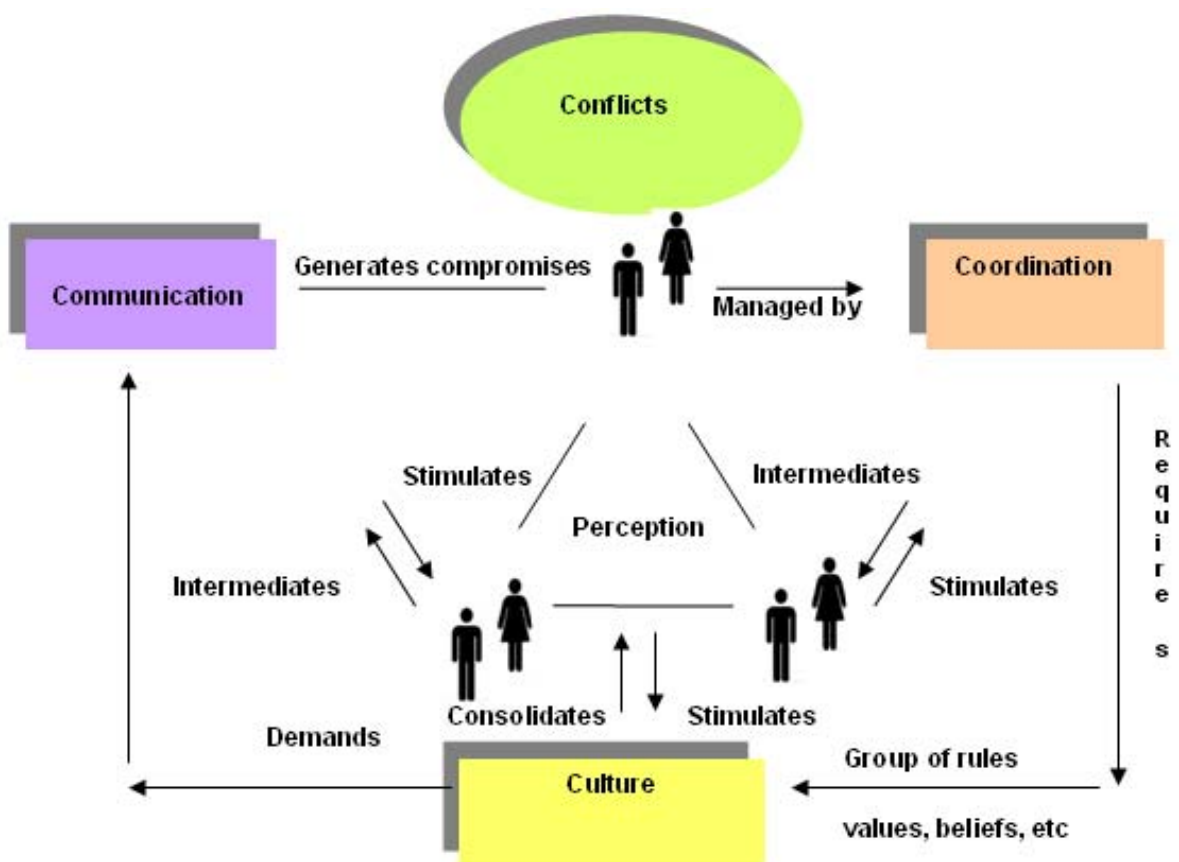

Figure 3. Conceptual trilogy of 'e-l@r Embrapa'. Source: Adapted from Fuks et al. (2002).

Communication must be guided by the assumptions that relationships in the research nets are complex, dynamic and fluid and do not follow a preestablished course. From this point of view, communication is seen as procedural and interactive and its role in the context of 'e-l@r
Embrapa' is to make feasible the learning promoted by social interactions, aimed at widening the chances for researchers to create new knowledge and competencies (Torres, Pierozzi Jr. and Pereira, 2009). The idea of collaboration involves that of coordination. Collaboration 
is the fruit of multiple efforts done by people who work together in one same process (Fuks et al., 2002). In the center of this definition is the idea of planning, which assures that the collective work results of a joint effort in the execution of individual tasks. Planning is to promote an additional effort so that collaboration can be obtained from the sum of individual efforts. Without the work of articulation (planning), researchers are at risk of getting involved in conflicting or repetitive tasks (Fuks et al., 2002).

The coordination/management of RD\&l projects involves pre-articulation of tasks, their management, and postarticulation. Pre-articulation of tasks is necessary to prepare the collaboration since it involves the identification of the work aims, their mapping in tasks and the selection of possibilities on how to execute them. The management of the course of tasks is the most dynamic step in the coordination process and requires that people have the capacity to negotiate, handle conflicts, establish new social contacts, and discuss new alternatives of solutions for the emerging problems. Post-articulation of tasks involves the assessment, analysis and reflection of the learning acquired by people over the task execution process and its documentation (process memory) so that it can serve as a study case for new learners and for organizational learning. Coordinating means to manage interdependence among tasks (Malone and Crowston, 1990) and in RD\&l institutions, especially Embrapa, this action has to be systemically and continuously formed to allow researchers to learn from one another and create knowledge and technologies in the course of task execution and articulation learning.

The organizational culture can be understood as a product of group learning and thus develops through the sharing of a group of beliefs, values, symbols and rules in the social interaction that occurs among people in a certain space. In this context, an organizational culture guided by common aims, in addition to integrating people, favors learning and knowledge generation, becoming one of the greatest challenges currently faced by companies (Schein, 1997). The dialog between organizational culture and knowledge generation is more than necessary since today the culture is noticed as a group of symbolic practices that exist in relation and in contrast to other practices. This indicates the existence of a more direct and strong association between the organizational culture and the creation of knowledge, on one hand, and learning, on the other hand
(Torres and Pierozzi Jr., 2009). It is extremely positive for the organizational culture in the e-l@r environment to be understood as a process that favors learning since recent studies carried out in the fields of social and cognitive psychology and anthropology have evidenced that learning occurs in sceneries presenting specific groups of rules and cultural and social expectations and these sceneries are extremely important because they influence not only learning but also the transference of what was significantly learnt (Bransford et al., 2007).

It is important to promote in Embrapa a closer dialog among these three aspects, since e-l@r will serve as a mediating channel simultaneously creating and consolidating values, beliefs and symbolic representations built and (re)built by people in the interaction process that occurred during the execution of net RD\&l project tasks, also serving to promote learning from the social relationships that occurred to solve research problems and create new knowledge among researchers.

\section{Final Considerations}

This proposal considers that RD\&l institutions also need to invest efforts in the promotion and creation of new knowledge and competencies, aiming at keeping the technological vanguard of its actuation fields. Embrapa has peculiarities and specificities that require researchers to have a higher capacity of analysis, synthesis, criticism and proposition of feasible and executable alternatives to reach the expected results. The market and social demands and the national challenges led it, on one hand, to identify new institutional arrangements to address and solve research problems and, on the other hand, to establish a management model capable of leading to the expected results. On this account, the formation of research nets is an alternative, i.e. the company assumes that these nets bring the possibility of promoting integrated solutions and simultaneously maximize the rational use of tangible and intangible resources, based on an interdisciplinary and transversal view of problems.

Considering this reality, the construction of collaborative environments to manage learning and knowledge in Embrapa's RD\&l nets is a proposal that plays a much more relevant role since it contributes to minimizing the challenges faced to perform the model of research nets, offering the possibility of reaching better results even 
because it assumes that the creation of new knowledge and competencies in its researchers results of integrated actions that cover the issue of communication, RD\&l project management and organizational culture. Thus, using ICTs as spaces for learning and as an open two-way channel which simultaneously integrates people in their daily social relationships and also provides the creation of new knowledge, competencies and learning (Kuhlen, 2003) can maximize the company's efforts towards new technological advances.

This perspective for an internationally renowned RD\&l institution, such as Embrapa, is important since innovation results of the construction of knowledge and this consequently results of a continuous interaction among individuals and is thus essential for the company to create "... a base strategy for innovation in its several dimensions and favor environments propitious for cooperation" (Santos, Botelho and Silva, 2006). Including those characteristics, 'e-l@r Embrapa' gives the possibility of promoting the dissemination of knowledge (learning), the follow-up of activities, and the use of suitable strategies to reach results (management), besides approaching competencies to exchange contents of common interests (relationship) to those integrating Embrapa's RD\&I nets.

\section{References}

AIRES, J.A., Ern, E. (2002). Os softwares educativos são interativos. Informática na Educação: Teoria e Prática, 5(I), 79-87.

ALVARENGA NETO, R.C.D., Barbosa, R.R. (2007). Knowledge management practices in the Brazilian organizational context: Toward the management of enabling contexts. In: Proceedings of VIII ENANCIB Encontro Nacional de Pesquisa em Ciência da Informação, Salvador, BA, Brasil. http://www.enancib.ppgci.ufba.br/ artigos/GT4--116.pdf [Accessed May 13, 2010].

ALVAREZ, A., Del Rio, P. (1996). Educação e desenvolvimento: a teoria de Vygotsky e a zona de desenvolvimento próximo. In: Coll, C., Palacios, J., Marchesi, A. (Eds.). Desenvolvimento psicológico e educação. Artmed, Porto Alegre. pp. 79-103.

BAKER, W. (1992). The network organization in theory and practice. In. Nohria, N. Eccles, R.G. (Eds.). Networks and organizations: structure, form, and action. Harvard Business School Press, Boston. pp. 397-429.

BRANSFORD, J.D., Brown, A.L., Cocking, R.R. (Org.) (2007). Como as pessoas aprendem: cérebro, mente, experiência e escola. Editora Senac São Paulo, São Paulo.

BRASIL. (2007). Formação de Redes. Ministério do Turismo. Coordenação Geral de Regionalização. Programa de Regionalização do Turismo. Brasília. http://www.ibam.org.br/publique/media/formacaoredes mi olo.pdf [Accessed May 18, 2010].

BULGACOV, S., Verdu, F.C. (200I). Redes de pesquisadores da área de administração: um estudo exploratório. Revista de Administração Contemporânea, 5(spe), 163-182.

CASTELLS, M. (1999). A sociedade em Rede. Paz e Terra, São Paulo.

CHILD, J. (1987). Information technology, organization, and response to strategic challenges. California Management Review, 30(I), 33-50.

CHOO, C.W. (1998). The knowing organization: how organizations use information to construct meaning, create knowledge and make decisions. Oxford University Press, New York.

DAMIANI, M.F. (2008). Understanding collaborative work in education and revealing its benefits. Educar em Revista, (3I), 213-230.

DIAS, C. (2005). Arquivos digitais: da des-ordem narrativa à rede de sentidos. In: Guimarães, E., Brum de Paula, M. R. (Eds.). Sentido e memória. Pontes, Campinas. pp. 4I-56.

ENGESTRÖM, Y. (1994).Teachers as collaborative thinkers: activity-theoretical study of an innovative teacher team. In: Carlgren, I., Handal, G.; Vaage, S. (Eds.). Teachers' minds and actions: research on teachers' thinking and practice. Routledge, London. Pp. 43-6I.

FISCHER, J. (200I). Por uma nova concepção da sociedade: uma análise política da globalização. Summus, São Paulo.

FORTES, D. (2006). Web 2.0. InfoExame, (243), 44-49. 
FRIGOTTO, G. (1995). Interdisciplinaridade como necessidade e como problema nas ciências sociais. In: Jantsch, A.P., Bianchetti, L. (Eds.). Interdisciplinaridade: para além da filosofia do sujeito. Vozes, São Paulo. Pp. 25-50.

FUKS, H., Raposo, A.B., Gerosa, M.A., Lucena, C.J.P. (2002). O Modelo de Colaboração $3 C$ e a Engenharia de Groupware. Pontifícia Universidade Católica, Rio de Janeiro.

GALLO, S. (2000). Transversalidade e educação: pensando uma educação não-disciplinar. In: Alves, N., Garcia, R.L. (Eds.). $O$ sentido da escola. DP\&A, Rio de Janeiro. pp. 36-37.

GEUS, A. (1997). The Living Company. Harvard Business Scholl Press, Boston.

GRAMKOW, A. (2000). Redes Relacionais entre Organizações: uma estratégia inovadora de sobrevivência. In: Proceedings of XX Encontro Nacional de Engenharia de Produção, São Paulo. http://www.abepro.org.br/ biblioteca/ENEGEP2000 E0035.PDF [Accessed April 19, 2010].

JAPIASSU, H. (1976). Interdisciplinaridade e patologia do saber. Imago, Rio de Janeiro.

JEONG, H., Chi, M.T.H. (1997). Construction of shared knowledge during collaborative learning. In: Proceedings of the 2nd International Conference on Computer Support for Collaborative Learning. Toronto. http://portal.acm.org/ citation.cfm?id=1599773.1599788 [Accessed June 16, 2010].

JONES, C., Hesterly, W.S., Borgatti, S.P. (1997). A general theory of network governance: Exchange conditions and social mechanisms. The Academy of Management Review. 22(4), 93 I-945.

KUHLEN, R. (2003). Change of paradigm in knowledge management: Framework for the collaborative production and exchange of knowledge. In: Word Library and Information Congress: $69^{\text {th }}$ IFLA General Conference and Council. http://www.kuhlen.name/MATERIALIEN/ Vortraege03-Web/rk ifla03 for publ300803.pdf [Accessed March I5, 2009].

LEVY, P. (1999). Cibercultura. Editora 34, Rio de Janeiro.
MALONE, T. W., Crowston, K. (1999). What is coordination theory and how can it help design cooperative work systems? In: Halasz, F., Proceedings of the 1990 ACM Conference on Computer-Supported Cooperative Work. ACM Press, New York. pp. 357-370.

NADLER, D.A., Tushman, M.L. (2000). A organização do futuro: as ligações mais importantes do século $X X$ e os próximos desafios que levarão ao novo desenho da empresa. HSM Management, 18, 58-66.

NONAKA, I., Konno, N., (1998). The Concept of "Ba": Building a Foundation for Knowledge Creation. California Management Review, 40(3), 40-54.

O'REILLY, T. (2005). What Is Web 2.0: Design Patterns and Business Models for the Next Generation of Software. http://oreilly.com/web2/archive/what-is-web-20.html [Accessed May 23, 2010].

ORLANDI, E.P. (2004). Interpretação. Pontes, Campinas.

PRIMO, A.F.T., Cassol, M.B.F. (1999). Explorando o conceito de interatividade: definições e taxionomias. Informática na Educação: Teoria e Prática, 2(2), 65-80.

ROCKWOOD, R. (1995). National Teaching and Learning Forum, 4(6), part I.

ROMANÓ, R.S. (2004). Ambientes virtuais para aprendizagem colaborativa no ensino fundamental. Athena Revista Científica de Educação, 2(2), 73-88.

ROSADO, A. (2008). A Wikipédia e suas contribuições para a aprendizagem cooperativa através da autoria textual coletiva. In: Proceedings of XIV ENDIPE - Encontro Nacional de Didática e Prática de Ensino. Porto Alegre. http://alexandrerosado.net78.net/attachments/003 ENDIPE XIVAlexandreRosado.pdf [Accessed March 25, 20I0].

SANTOS FILHO, J.C. (1999). A interdisciplinaridade na universidade: perspectiva história. Revista Educação Brasileira, 2 I (43), I I-4I.

SANTOS, H. (2007). Innovation and institutional arrangements: contributions to a theoretical analysis of innovation networks. Liinc em Revista, 3(2), I I3-I23. 
SANTOS, D.A., Botelho, L., Silva, A.N.S. (2006). Ambientes Cooperativos no Sistema Nacional de Inovação: o suporte da gestão do conhecimento. In: Proceedings of Conferência Sul-Americana em Ciência e Tecnologia Aplicada ao Governo Eletrônico. III CONeGOV 2006. http://www.ngs.ufsc.br/wpcontent/uploads/2010/05/SORATTO SANTOS BOTELH O 2006.pdf [Accessed August 31, 2009].

SCHEIN, E. (1997). Organizational culture and leadership. Jossey-Bass, São Francisco.

SCHLEMMER, E. (2002). AVA: Um ambiente de convivência interacionista sistêmico para comunidades virtuais na cultura da aprendizagem. Universidade Federal do Rio Grande do Sul, Porto Alegre. http://gpedunisinos.files.wordpress.com/2009/07/tsumaf.pdf [Accessed August 26, 2009].

SCHLEMMER, E., Fagundes, L. C. (200I). Uma proposta para avaliação de ambientes virtuais de aprendizagem na sociedade em rede. Informática na Educação: Teoria e Prática, 4(2), 25-36.

SCHLEMMER, E., Saccol, A.Z., Garrido, S. (2007). A model for assessing software as a support for distance learning. Reista de Gestão USP, I4(I), 77-9I.

SCOTTA, L. (2009). Da enciclopédia e da Wikipédia: uma leitura discursiva. Artefactum, (2), 7I-82.

SILVA, M. (2006). Sala de aula interativa. Quartet, Rio de Janeiro.

SOO, C., Devinney, T.M., Midgley D.F., Deering A. (2002). Knowledge management: philosophy, process, pitfalls, and performance. California Management Review, 44(4), I29-I5I.

TÔRRES, J.J.M. (2005). Teoria da complexidade: uma nova visão de mundo para a estratégia. In: Proceedings of $I$ EBEC. http://www.facape.br/ruth/adm-filosofia/Texto 5 Teoria da Complexidade e Estrat.pdf [Accessed August 5, 2009].

TORRES, T.Z., Pierozzi Júnior, I. (2009). Redes cooperativas em instituição de PD\&l: uma abordagem integrada à gestão do conhecimento. WORKSHOP BRASILEIRO DE INTELIGÊNCIA COMPETITIVA E GESTÃO DO CONHECIMENTO, 9. Belém. http://www.infoteca.cnptia.embrapa.br/handle/item//6883

[Accessed April 20, 2010].

TORRES, T.Z., Pierozzi Junior, I., Pereira, N.R. (2009). Gestão do conhecimento em Instituição de Pesquisa, Desenvolvimento e Inovação (PD\&l): abordagem processual integrada. http://www.infoteca.cnptia.embrapa. br/bitstream/item/I3653/I/LI5IGB.pdf [Accessed May I5, 2010].

TUSHMAN, M., Nadler, D.A. (1986). Organizing for innovation. California management review. 28(3), 74-92.

VYGOTSKY, L.S. (1998). A formação social da mente. Martins Fontes, São Paulo. 